\title{
ANTHIAS FORMOSUS.
}

\section{*⿻ำ \\ CHARACTER GENERICUS.}

Caput totum squamosum; operculo anteriore serrato.

Bloch. ichth. 9. p. 86.

CHARACTER SPECIFICUS, छc.

ANTHIAS flavus, lineis longitudinalibus cæruleis.

Perca formosa.

Lin. Syst. Nat. Gmel. p. 1322.

Perca marina capite striato.

Catest. Car. 2.t. 6.

In maribus Americanis præcipue conspicitur Anthias formosus, longitudine, ut plurimum, pedali. 


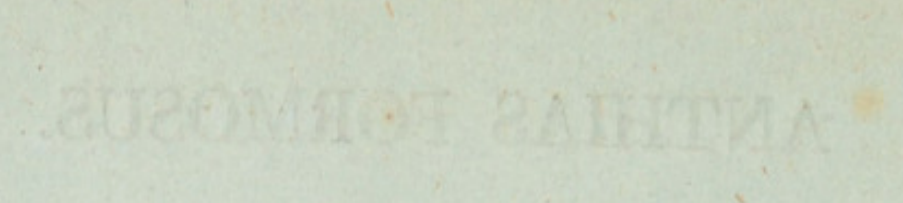

$2+2 x^{2} x^{2}$

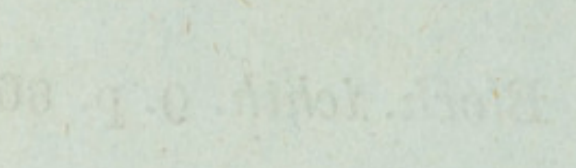

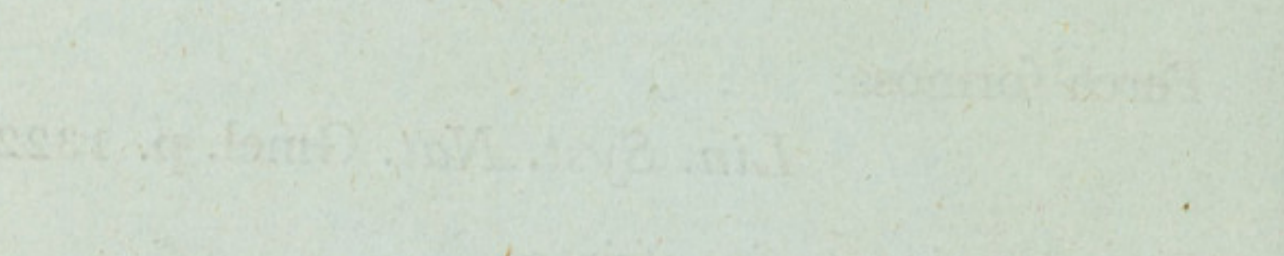





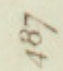

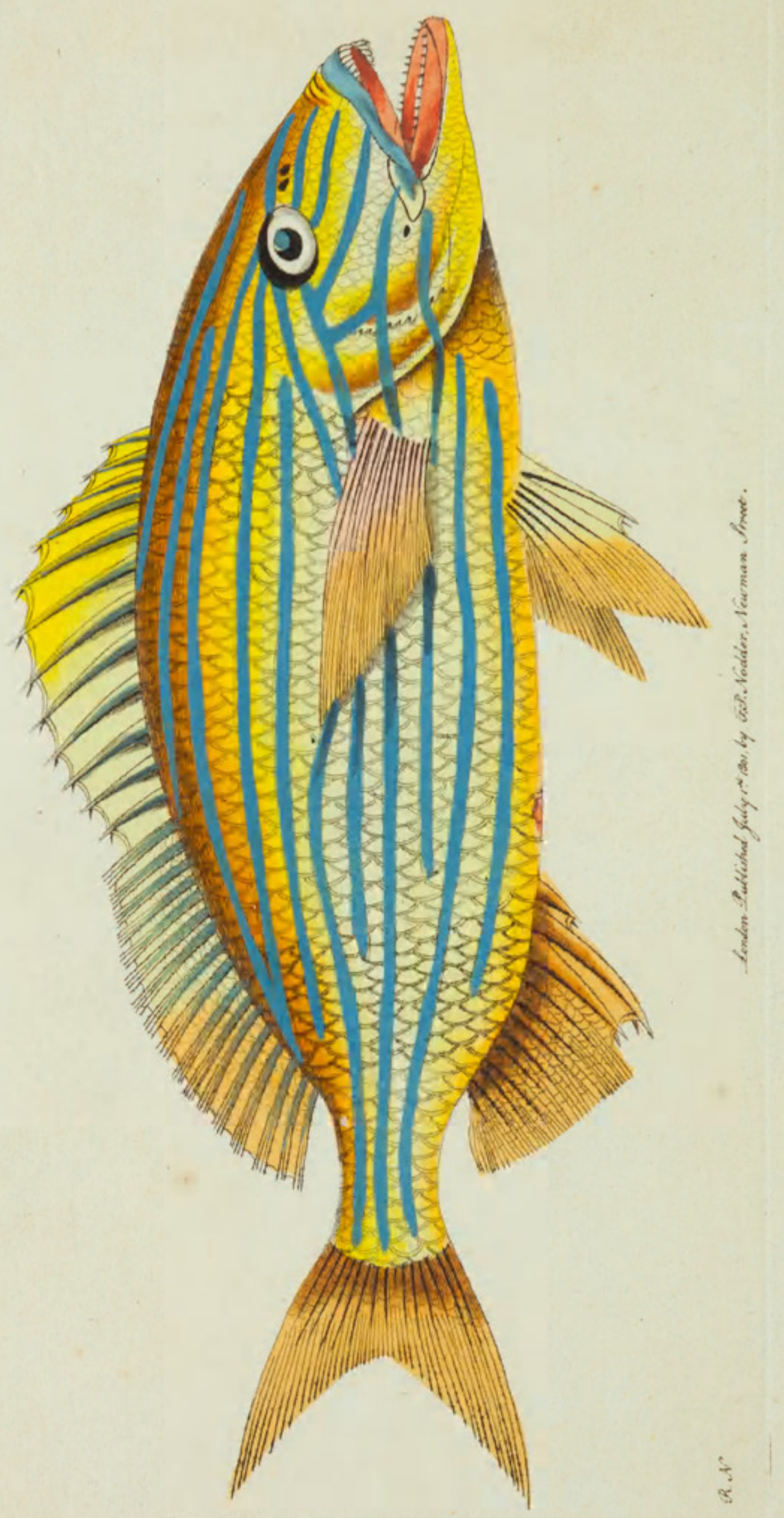




\section{THE BLUE-STRIPED ANTHIAS.}

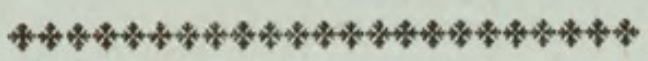

\section{GENERIC CHARACTER.}

Head completely scaled: anterior gill-cover serrated.

\section{SPECIFIC CHARACTER, छ̈C.}

Yellow ANTHIAS with longitudinal blue lines. The Grunt.

$$
\text { Catesb. Carol. 2. p. } 6 .
$$

L'Ecuriel.

Bonaterre Encycl. Ichth. p. 135. Der Rothmund.

$$
\text { Bloch. ichth. pl. } 323 .
$$

This beautiful fish is principally found in the American seas, and is generally about twelve inches in length. 


\section{$2 \mathrm{BHL}$ Biodiversity Heritage Library}

Shaw, George. 1800. "The Blue-Striped Anthias, Anthias formosus [PI. 487]." The Naturalist's Miscellany 12(CXXXVI), https://doi.org/10.5962/p.310933.

View This Item Online: https://www.biodiversitylibrary.org/item/278722

DOI: https://doi.org/10.5962/p.310933

Permalink: https://www.biodiversitylibrary.org/partpdf/310933

\section{Holding Institution}

Museums Victoria

\section{Sponsored by}

Atlas of Living Australia

\section{Copyright \& Reuse}

Copyright Status: Public domain. The BHL considers that this work is no longer under copyright protection.

This document was created from content at the Biodiversity Heritage Library, the world's largest open access digital library for biodiversity literature and archives. Visit BHL at https://www.biodiversitylibrary.org. 